\title{
ПРЕНОШЕЊЕ АКЦЕНТА НА ПРОКЛИТИКУ У ГОВОРУ СЕЛА БАТКУША КОД ШАМЦА ${ }^{1}$
}

\section{САЖЕТАК}

У раду се анализира преношење акцента на проклитику у селу Баткуша, чији говор припада сјевероисточном подручју херцеговачко-крајишког дијалекта. Истраживањем је обухваћено преношење акцента на проклитику са свих врста ријечи које учествују у овом процесу, а ова је појава кроз анализу посматрана према врстама ријечи и према типу преношења. Циљ овог рада јесте да покаже колико је преношење акцента на проклитику у говору села Баткуша жива појава, у којим категоријама се јавља и у којој мјери, има ли тенденције напуштања ове појаве, који лингвистички и екстралингвистички фактори утичу на њену досљедност, те каква је она у односу на ситуацију у сусједним и удаљенијим српским говорима. Анализа показује да је стање у говору Баткуше, када су у питању интензитет преношења акцента на проклитику и категорије у којим се оно врши, у знатној мјери блиско приликама које су познате већини говора херцеговачко-крајишког дијалекта.

КљУЧНЕ РИЈЕЧИ: дијалектологија, преношење акцента на проклитику, херцеговачко-крајишки дијалекат, посавски говорни тип.

\section{1. Увод}

У раду је приказано преношење акцента на проклитику у говору села Баткуша, које припада општини Шамац у Републици Српској. Село је смјештено у Босанској Посавини, 14 км југоисточно од Шамца и 17 км југозападно од Орашја, поред кога је П. Ивић (2001: 176) повукао границу

\footnotetext{
${ }^{1}$ Рад представља скраћену и прилагођену верзију мастерског рада одбрањеног 2019. године на Филозофском факултету у Новом Саду.
} 
херцеговачко-крајишког дијалекта. У Орашју је и државна граница између Републике Српске и Републике Хрватске.

Говор Баткуше припада сјевероисточном огранку херцеговачкокрајишког дијалекта са ијекавско-јекавском замјеном јата (в. дијалектолошку карту у Ивић 2001). Припада новоштокавским говорима који познају четири акцента и постакценатску дужину, као и стандардни српски језик. ${ }^{2}$

Грађа за овај рад сакупљана је 2014. године. Испитано је шесторо информатора - четири жене (И1, И3, И4, И5) и два мушкарца (И2, И6), различитог, али ниског нивоа писмености. Информатори су припадници средње и старије генерације (И1 - 1932. годиште; И2 - 1956; ИЗ - 1944; И4 1949; И5 - 1937; И6 - 1947). Корпус је сачињен на основу трију аудио-записа у трајању: И1, И2 - 74' 4"; И3, И4, И5 - 46' 40"; И6 - 78' 51". Ниједан информатор нема потешкоће приликом артикулације гласова. Информатори најчешће говоре о свакодневним обавезама, међуљудским односима, рату, болести, смрти, пословима у домаћинству, у пољу и око стоке, те осталим темама које их преокупирају.

Ауторка није говорник овог говорног типа. Од рођења је, поред бањалучког, слушала говоре Жупе, Лијевча поља и Поткозарја. Разлог избора говора из ове групе јесте то што су српски посавски говори донедавно мање истраживани од других говора херцеговачко-крајишког дијалекта. Први обимнији приказ говорних особина становништва ових простора дали су Д. Вујичић, Д. Брозовић, А. Пецо и Ј. Баотић у заједничком извјештају Говори сјеверне и сјевероисточне Босне (1985). Преношење акцента на проклитику тамо је обрађено, и то спорадично, уз

2 У грађи за овај рад примијећена је дјелимична или потпуна редукција постакценатских дужина у генитиву и инструменталу једнине именица женског рода

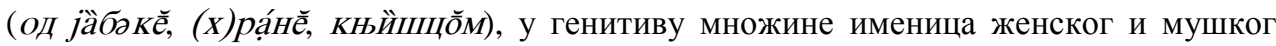
рода (сеста́рӑ, сино́ва), код придјева одређеног вида (дй ија ба̀ба, хр̀ва̄цко мјёсто), у компаративу и суперлативу придјева (потрѐбније, стрӧгијё, на̣̂jва̀жнијӗ), код

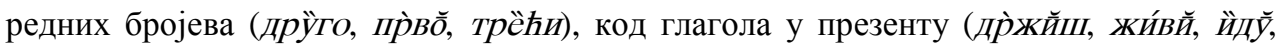
пйшў), перфекту, тамо гдје је дошло до сажимања вокала (рёкб̆, сви́ро), аористу (нё

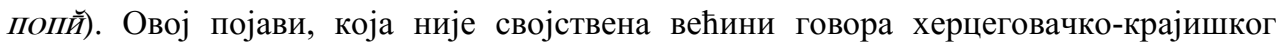
дијалекта, ауторка ће посветити пажњу другом приликом. 
акценте појединачних врста ријечи, тако да је тешко добити општу слику. Поред тога, с обзиром на касније провјере које су показале грешке теренских истраживача, ове налазе треба узимати са озбиљном резервом (Козомара 2016: 603-604). Нешто систематичнија истраживања овог говорног комплекса започета су почетком овог вијека. М. Драгичевић (2002; 2004) писао је о говору требавских Срба, затим о говору села Бранешци код Челинца (2003), Бање Врућице крај Теслића (2007), села Кремне код Прњавора (2008), трију насеља у околини Дервенте (2010; 2011). О различитим језичким нивоима говора сјеверног огранка херцеговачко-крајишког дијалекта писали су и С. Танасић (2000; 2004a; 2004б; 2006; 2007; 2009), Д. Козомара (2003), Д. Црњак (2006; 2007; 2009a; 2009б; 2011), С. Цукут (2013). Међу описима ових говора у новије вријеме посебно се истиче рад Фонетске и морфолошке особине српских посавских говора између Врбаса и Укрине (Козомара 2016), утемељен на грађи из 28 истражених пунктова српских говора на подручју општина Србац, Прњавор, Дервента и Босански Брод.

У раду се анализира акценатски вид проклизе у говору аутохтоних становника Баткуше. Рађена је потпуна ексцерпција грађе у транскрипту. Примјери преношења акцента на проклитику, као и одступања од ове појаве, разврстани су по морфолошком критеријуму, односно по врсти којој акцентогена ријеч припада. Унутар основне подјеле, примјери су даље класификовани према типу преношења (старо, ново) и врсти проклитике, а навођени су азбучним редом.

Почетак интересовања лингвиста за преношење акцента на проклитику старијег је датума. М. Решетар у свом дјелу Die serbocroatische Betonung (1900) обрадио је, на основу њему доступног материјала, преношење акцента са свих врста ријечи које учествују у овом процесу. Ђ. Даничић (1925) анализирао је преношење акцента са именица. Дијахроно објашњење ове појаве дали су А. Пецо (1971) и А. Белић (1999). А. Пецо приказао је акценатске промјене које су претходиле стању у стандардном језику, наводећи и примјере преношења акцента на проклитику. Приликом истраживања ове теме незаобилазна је студија Б. Николића (1970), у којој је обрађен акценатски вид проклизе са свих врста ријечи. У новије вријеме све је више извјештаја посвећених овој теми. Д. Зец (2000) писала је о преношењу акцента са замјеница на везнике $u$ и ни под утицајем реченичног фокуса у београдском говору. 3. Симић (2004) испитивао је 
преношење акцента на проклитику у говору Гласинца, Д. Радовановић (2007) у говору Ваљевске Колубаре, Ж. Бошњаковић (2009) у говору Новог Сада, М. Петровић Савић (2012) у говору Рађевине, Ј. Лукић (2017) у говору села Винска, С. Цукут (2017) у говору околине Шипова. Многи радови о појединачним говорима садрже бар опште напомене о овој теми (Пецо 1957; Николић 1966; Петровић 1973; Симић, М. 1978; Ђукановић 1983; Ивић и др. 1994; Далмација 1997; Козомара 2016 итд.).

Циљ овог рада је да покаже колико је преношење акцента на проклитику у говору села Баткуша жива појава, у којим категоријама се јавља и у којој мјери, има ли тенденције напуштања ове појаве, који лингвистички и екстралингвистички фактори (в. т. 2.3.) утичу на досљедност ове појаве, те каква је она у односу на ситуацију у сусједним говорима и удаљенијим српским говорима.

\section{2. Теоријски оквир}

\section{1. Акценатски систем српског језика}

Савремени стандардни српски језик заснива се, у акценатском смислу, на млађој новоштокавској акцентуацији, која представља систем од четири акцента: краткосилазни [ " ], краткоузлазни [ ' ], дугосилазни [ ] , дугоузлазни ['], и два неакцентована квантитета: дужине [-] и краткоће [` ]. Млађа новоштокавска акцентуација заједничка је за шумадијсковојвођански дијалекат, млађе икавске говоре и херцеговачко-крајишки говорни тип (Николић 1970: 11), чијем сјевероисточном огранку припада и говор Баткуше. Овај акценатски систем настао је помјерањем силазних акцената са свих непрвих слогова према почетку ријечи (Петровић 1996: 88). Преношењем акценатског врхунца на кратак слог настао је [ '], а преношењем на дуги слог добијен је [']. На старом мјесту пренесеног дугог акцента остала је неакцентована дужина [- ] (Белић 1999: 141). Новоштокавским преношењем успостављена су јасна дистрибуциона правила: силазни акценти могу да стоје на једином слогу и на почетном слогу вишесложних ријечи, узлазни акценти могу да стоје на сваком слогу осим посљедњег, а посљедњи слог код двосложних и вишесложних ријечи остаје неакцентован. Неакцентована дужина може да се нађе само у позицији послије акцентованог слога, а неакцентовани кратак вокал може 
бити и испред и иза акцента (Subotić i dr. 2012: 97-99). Наравно, у дијалектима се сусрећу одступања од ових правила.

\section{2. Акцентогене ријечи и клитике}

Акценат имају само акцентогене или (орто)тоничне ријечи, које најчешће припадају пунозначним или аутосемантичким ријечима. Поред ортотоничних ријечи постоје и такозване граматичке или функционалне ријечи, које немају свој акценат, али са акцентогеним ријечима чине јединствену фонолошку ријеч или акценатску цјелину. Те ненаглашене ријечи су клитике, а у зависности од тога да ли се налазе испред или иза акцентогене ријечи, прецизније се називају проклитике и енклитике. Проклитике, које стоје испред наглашених ријечи, могу у неким случајевима понијети акценат, који на њих прелази са силазно наглашене ријечи, док енклитике никада не могу понијети акценат. У проклитике се убрајају предлози, везници и рјечца не (Subotić i dr. 2012: 105-106).

\section{3. Преношење акцента на проклитику}

Преношење акцента на проклитику је, у синтаксичком смислу, најкарактеристичнија појава у говорима са млађом новоштокавском акцентуацијом (Николић 1970: 14). Када се испред ријечи са силазним акцентом на иницијалном слогу нађе проклитика, тај силазни акценат може да се пренесе на проклитику. Међутим, ова појава није једнако заступљена у свим српским говорима. Када је ријеч о њеној досљедности, на српском језичком простору издвајају се двије зоне: сјевероисточна, у којој преношење није досљедно, и југозападна и западна, у којој је ова појава још жива (Николић 1970: 35). Другим ријечима, преношење акцента на проклитику данас је обичније у ијекавским него у екавским говорима (Пецо 2002: 70; Бошњаковић 2007: 81). У српском језику постоје двије врсте преношења акцента на проклитику: старо (прасловенско, метатаксичко) и ново (новоштокавско, метатонијско) преношење.

На (не)преношење акцента на проклитику утичу лингвистички фактори, као што су структура акцентогене ријечи и проклитике (број слогова, јунктура), граматичка категорија акцентогене ријечи (врста ријечи), семантика акцентогене ријечи (топоними, антропоними итд.), њена функција у реченици (објекат, прилошка одредба), учесталост употребе 
дате синтагме. Поједини аутори указују на екстралингвистичке факторе који могу утицати на преношење акцента на проклитику, наводећи да је оно карактеристично за нормалан говор, а не емфатичан, те да је важна улога традиције, односно насљеђивање говорних особина старијих генерација (в. Бошњаковић 2009: 79-82).

\subsection{1. Старо (прасловенско) преношење акцента на проклитику}

Проклитика може да понесе акценат са облика ријечи на чијем се првом слогу налази стари силазни акценат ( $\ddot{y}$ главву, нӓ земљу). На проклитици је краткосилазни акценат. Ако је проклитика двосложна, пренесени акценат наћи ће се на њеном првом слогу. Ово преношење јавља се, у већој или мањој мјери, у свим српским говорима, а познато је и у другим словенским језицима. Наведене измјене у акцентуацији извршене су или у балтичко-словенској епоси или у раном периоду посебног живота словенске језичке заједнице (Пецо 1971: 31).

\subsection{2. Ново (новоштокавско) преношење акцента на проклитику}

Новоштокавско је преношење са слогова који имају нове силазне

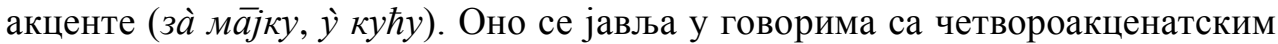
системом, а на проклитици је узлазни акценат (Николић 1970: 35). Ако је проклитика двосложна, пренесени акценат наћи ће се на њеном другом слогу. Ово преношење уобичајено је у ијекавским говорима херцеговачког типа, али није и у екавским новоштокавским говорима, гдје све више преовладава акценат засебних ријечи (Пецо 1971: 52).

\section{3. Анализа грађе}

\section{1. Преношење акцента са именица}

У говору Баткуше остварују се и старо и ново преношење акцента са именице, на једносложне и двосложне предлоге, те на везнике $u$ и $н и$.

\subsection{1. Прасловенско преношење акцента са именица}

Прасловенско преношење акцента са именица јавља се код именица сва три рода. 
Силазни акценат забиљежен је на предлозима у вези са именицама женског рода на -a, типа гла́ва, ру́ка, зѐмља, (n)чѐла, код којих се у акузативу једнине и множине јавља алтернација: дугоузлазни $\rightarrow$ дугосилазни, односно краткоузлазни $\rightarrow$ краткосилазни акценат:

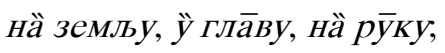

мёђу челе.

У идиолекту И6 именица (n)чела у свим падежима једнине има краткоузлазни акценат, а у множини краткосилазни. Забиљежени су и примјери са непренесеним акцентом код именица овог типа: за зимму, $y$ пчёле, што се може тумачити као посљедица говорног ритма.

Према прасловенском типу преношења акценат се помјера на предлог са облика акузатива једнине именица женског рода на сугласник:

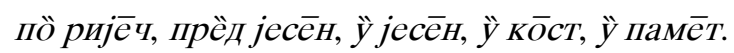

Прасловенско помјерање акцента на проклитику са именица типа земља и глава, те именица женског рода на сугласник, остварује се и у западнобосанским ијекавским говорима (Дешић 1976: 210), у српским говорима Поткозарја (Далмација 1997: 52), Бање Врућице крај Теслића (Драгичевић 2007: 354), Лапачког поља (Драгичевић 2009: 292), подручја између Врбаса и Укрине (Козомара 2016: 666), околине Шипова (Цукут 2017: 680-681), Босанског Брода (Лукић 2017: 225, 232, 235), као и Рађевине (Петровић Савић 2012: 218, 220). У пиперском говору

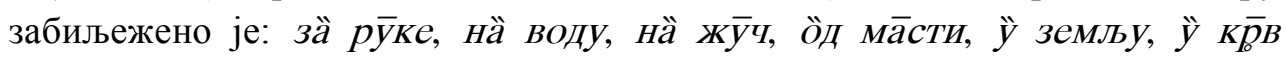
(Стевановић 1940: 122-123, 129). У змијањском говору исто је у акузативу

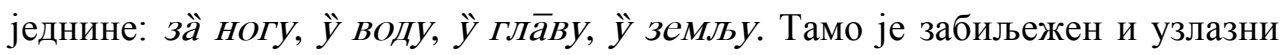
акценат на везницима испред једносложних именица женског рода на сугласник: ѝ ра̄ж, нй ражи (Петровић 1973: 19-20, 104). У селу Обади у околини Калиновика код готово свих категорија регистрована је могућност паралелног појављивања старог и новог преношења, као и непренесених акцената. Тамо стоји: нӑ земљу, нйз воду, прё зору, али: кро̀за земљу, нӑ

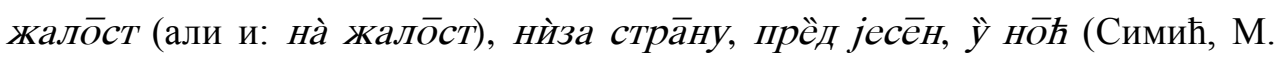


1978: 22). Преношење акцента са именица женског рода на сугласник у говору височких муслимана метатонијског је типа (Valjevac 1983: 301-302).

Прасловенско преношење сачувано је у генитиву и акузативу једнине именица мушког рода, типа бог, мјесеи, син:

йз Дома̄љевца, иेз Осијёка, оेд бога, ӧ(д) свијетта, оेт сйна;

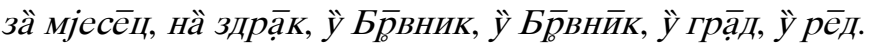

По старом типу акценат се преноси на предлог са облика генитива и локатива једнине именица средњег рода:

йз брда, йза јутра, ӧ(д) срца;

нӓ гроббљу.

Посљедњи наведени примјер не уклапа се у Даничићева начела о преношењу акцената са именица средњег рода (1925: 75). И у говорима Бање Врућице и Лапачког поља забиљежено је: краัj гроббља, ў гроббе (Драгичевић 2007: 354; 2009: 292).

Код прасловенског преношења акцента на двосложни предлог акценат се по правилу јавља на првом слогу предлога: мёђу челе, йза јутра, као код Даничића (1925: 5-14). Међутим, у појединим говорима није овако. У говорима у сливу Студенице, у којима је неоакут сачувао свој фонолошки статус, у акценатској проклизи силазни акценат на двосложном предлогу најчешће је на другом слогу: прекӧ брда, прекӧ дана, међуे људде (в. Драгин 2000: 167-169). М. Стевановић у пиперском говору биљежи изӓ борра, испӧд гууња, паралелно са йза борра, мймо плот (1940: 85-86, 97). У опису источнобосанског ерског говора нашли смо један овакав примјер: изӓ ограде (Реметић 2000: 517).

Старо преношење на саставни везник нашло се у конструкцији:

й да̄H-да̀нас.

\subsection{2. Новоштокавско преношење акцента са именица}

Ново преношење такође је присутно код именица сва три рода. Забиљежено је у знатно већем броју примјера него прасловенско. Најчешће 
се јавља код именица женског рода на - $a$ са силазним акцентом на првом слогу. На предлоге, једносложне и двосложне, акценат се преноси са облика генитива, акузатива и локатива једнине и множине, те инструментала једнине:

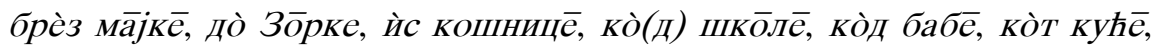

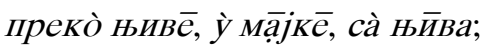

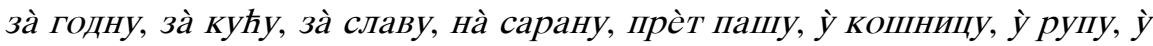

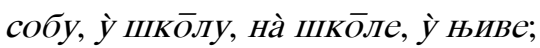

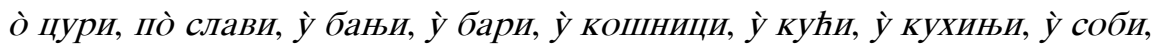

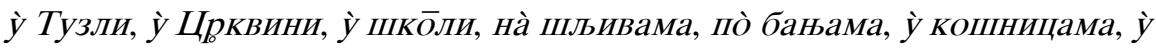
трњкама, у̀ шумама;

за̀ $K y \hbar \bar{o} M$.

Ново преношење акцента на предлог забиљежено је са именица мушког рода у генитиву, акузативу и локативу једнине, те инструменталу множине:

й(з) Жаба̄ра, ко̀(д) Цвијётна,

на̀ дједа, на̀ курс, на̀ Шамац, у̀ дједа, у̀ подрум (ова именица ван проклизе забиљежена је са силазним акцентом, као пӧдрум и пӧдрма), у̀ Шамац, у̀з дједа;

уे Шамцу,

по̀т прстима.

У грађи се нашао само један примјер метатонијског преношења акцента са именице средњег рода:

на̀ дворйште.

Преношење са именица pluralia tantum на предлог такође је ново, а примјери су забиљежени код именица мушког рода у локативу: на̀ Русовићима, у̀ Русовићима, те средњег рода у инструменталу и акузативу: по̀д јаслама, по̀д јасле. Код облика генитива мушког рода и локатива 
женског рода преношење је изостало: из Вйнкова̄ца,, на Грёбницама. Разлог изостанка проклизе у овом случају је број слогова у топониму.

У конструкцији до̀ ће̄рке преношење је аналошко (вјероватно према

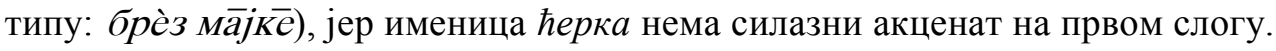
Примјер иза̀ ногу такође је аналошки. На проклитикама испред именица типа нога, глава, акценат је силазни (в. т. 3.1.1; уп. Даничић 1925: 4-7; Николић 1970: 37).

Код новоштокавског преношења акцента на двосложни предлог акценат се по правилу јавља на другом слогу предлога: иза̀ ногу, преко̀ њивё.

На везник $u$ акценат се најчешће преноси са облика номинатива, датива и акузатива једнине фреквентних именица баба и мајка:
й баба;
ѝ баби, ѝ ма̄jки,
иे бабу.

Бројни су примјери преношења акцента на везнике $u$ и $н и$ са облика једнине прва четири падежа именица мушког рода:

й дјед, й доктор, й доктор, ѝ Петар;

й дједа;

й доктору;

нй теча̄j.

Примјери преношења акцента на проклитику са именица показују да се оно врши по Даничићевим начелима, мада не толико досљедно, што илуструју бројни примјери одступања од ове појаве.

\subsection{3. Конструкције са непренесеним акцентом}

У грађи за овај рад има и примјера у којима именица пред проклитиком задржава акценат. Наводимо неколико таквих примјера:

из Виннкова̄ца̄, ис Пёлагићева, ко(д) црิкве, од бӧлести, од гра̣̂да; за зйму, за трён, на ма̣̂jку, прет пӓшу, у кӧшницу, у пчёле, у чйн, 
са до̆ктором, са цйљем;

наа Гарревцу, на кӧшницама, на лоิгорова̄њу, на мйшци, у Тўзли, и грйпа, и / дјёд, и јёсён, и наумјештај, ии / стиिд, и суิнце, ни дўлум, и / гроิжђа, и по̆лена.

У литератури је много пута потврђено да што је ријеч дужа, то теже оставља акценат (Даничић 1925: 58; Козомара 2006: 666): из Вйнкова̄ца, ис Пёлагићева, на лоิгорова̄њу, на кӧшницама итд. Сагласно томе, и у овој грађи најчешћи су примјери преношења акцента са једносложних и двосложних, а затим и тросложних ријечи. Међутим, забиљежено је и неколико примјера преношења акцента са четворосложних именица: йз

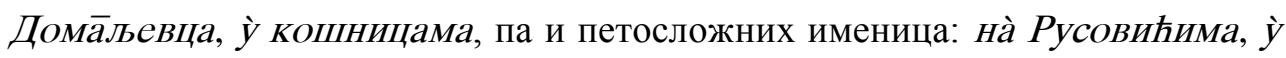
Русовићима.

Најбројнији примјери непренесених акцената са именица забиљежени су код И6, мада и у његовом идиолекту постоје и примјери са пренесеним акцентима. Разлози непреношења акцента са именица у говору И6 могли би бити психолошки мотивисани, јер нам овај информатор говори о пчеларству, о коме претпоставља да не знамо ништа. Он се труди да нас упути у своје занимање, због чега је темпо његовог говора најспорији. Овом мишљењу у прилог иде чињеница да код И6 нема одступања од преношења акцента са замјеница, будући да нема потребу да их наглашава јер семантичко тежиште никада није на њима него на терминима (именицама). Код овог информатора постоје именице које у једном примјеру препуштају акценат проклитици, а у другом га задржавају пред проклитиком. Интересантно је што су одступања од преношења готово увијек код првог помињања именице (термина), а када се иста ријеч помене други пут, долази до проклизе:

a1) Иду и у̀лазе у пчёле. а2) Ја су̀тра моิрам мёђу челе. а3) Отац је слаัбо во̀лијо мёђу челе.

б1) Враิтиш брзйно̄м оно са̀ће и кӧшницу на̀ исто мјёсто. б2) Чỳjе се уे кошници. 


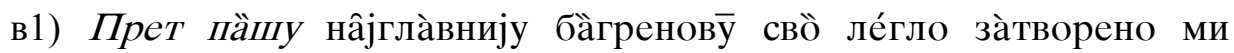
мётне̄мо го̆ре. в2) И то̂ ра̂димо прёд на јѐдно пѐтнёст-два̀јест да́на прѐт пашу.

Поред горенаведених разлога одступања од проклизе, именица задржава акценат и у сљедећим случајевима:

- када је под емфазом: ко(д) цркквё, на ма̣̂jку, од гра̣̂да, у Ту̀зли,

- код оклијевања у изговору: наа Гаิрёвцу,

- $\quad$ када се између проклитике и именице нађе пауза: и/ грожжђа, и/ дјёд,

- када је именица у рјеђој употреби: и наัмјештај, на мйшци, у заิсједи.

Са именица типа брзйна нема потврда за преношење акцента на проклитику (на брзйну) као код Даничића (1925: 11). Примјери проклизе са именица овог типа нису забиљежени ни у говору посавског села Кострча (уп. Баотић 1979: 219), ни у западнобосанским ијекавским говорима (Дешић 1976). Преношења акцента са именица типа брзйна, поред чешћих

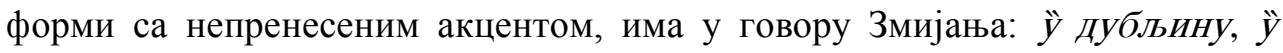
планину (Петровић 1973: 189, 190), Лапачког поља: нӑ брзину, нӑ срамоту, ӱ висину, у̀ ширину (Драгичевић 2009: 292), те у говорима између Врбаса и Укрине, мада ријетко (Козомара 2016: 666). У говорима Пиве и Дробњака регистровано је: нӓ бистрине, нӓ ведрину, на̀ старину, پ̆ родбину (Вуковић 1940: 234-235).

У источнобосанском ерском говору акценат се са именица на предлоге преноси по истом принципу у истим категоријама као и у нашој грађи: за̀

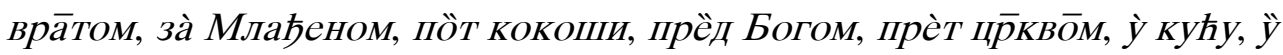
сијено (в. Реметић 2000), односно по Даничићевим начелима. Такво је преношење акцента са именица у говорима Поткозарја (Далмација 1997: 50-55), Змијања (Петровић 1973: 19-20, 145, 148-152), Лике (Драгичевић 
2007: 354-355; 2009: 291-292, 294), Посавине (Козомара 2016: 666-667), околине Зворника (Ђукановић 1983: 387), као и у западнијим српским говорима (Дешић 1976: 210), мада се у сваком од њих, као и у говору Баткуше, могу чути и аналошке форме, а и непренесени акценти, те се и тамо констатује да је преношење акцента са именица редовна, али не и апсолутна појава. Акценатска проклиза биљежена је у истим категоријама и у говорима Мачве (Николић 1966: 216-217), Тршића (Николић 1968: 387), Баната (Ивић et al. 1994: 77-92), мада много недосљедније. Дакле, преношење акцента са именица на проклитику у нашој грађи јавља се у истим категоријама као код Даничића, као и у другим горенаведеним српским говорима. Разлика између говора Баткуше и поменутих говора очитује се у досљедности ове појаве (уп. Николић 1970: 35).

\subsection{4. Још неке напомене у вези са акцентом именица}

У говору Баткуше честа је појава дезакцентуације заједничких именица које стоје уз лична имена, а означавају тип односа говорника према тој особи. Ријеч је о именицама типа баба, прија, пријатељ: Кад и баба А̣̂нка до́ђе по̀слијё. | Кӧје̄ ти је баба Јáња? | Тво̀ја баба Сája, фа́ла бо̀гу, доेбро. | Прија Ру́жа ѝшла у спро̀вод. | Ако трёба̄ нёшто по̀слушати пријатеља Пе́ру, ту̂ је прија Аُнђа. У оваквим синтагмама прва именица се доживљава као одредница и у датом моменту тежиште информације није на њој. Дезакцентуација ортотоничне ријечи искључује могућност преношења акцента на проклитику испред ње.

У идиолекту И1 забиљежено је: баба Ја́ња, баба Са́ја. Међутим, ако је именица баба акцентована, и ако се испред ње нађе проклитика, обавезно долази до преношења акцента: ѝ баби Са́ји, ко̀д бабе А̣́нђе̄. Код ИЗ именица баба уз лично име није забиљежена са акцентом: баба А̣̂нка, баба Бо́jа, баба Ма́ра. Ова појава честа је у говорима Баната (Ивић et al. 1994: 75-76) и призренско-тимочке области (Трајковић 2015: 480).

\section{2. Преношење акцента са замјеница}

У говору Баткуше остварују се и старо и ново преношење акцента са замјенице, на једносложне и двосложне предлоге, те на везнике $u, н и$ и већ. 


\subsection{1. Прасловенско преношење акцента са замјеница}

Малобројни примјери старог преношења забиљежени су код И1, ИЗ и И4. Акценат је пренесен на предлог са облика инструментала једнине и генитива множине личне замјенице првог лица, те генитива једнине повратне замјенице себе:

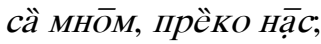

оेко себе.

Акценатска проклиза типа сä $M H \bar{O} M$, că тоб $\bar{o} M$ представља општесрпскохрватску појаву (Николић 1970: 47).

Старо преношење на двосложни предлог забиљежено је у два примјера: ӧко себе, прёко нӑ̣c.

На везнике $u$ и већ ('него') краткосилазни акценат пренесен је са облика номинатива једнине и множине показних замјеница:

й тер, вёћ онй, й ови.

У конструкцији й они преношење је аналошко, јер лична замјеница трећег лица множине у номинативу нема силазни акценат на првом слогу.

Стари тип преношења у говору Змијања забиљежен је само у конструкцијама са личним замјеницама, и то њиховим краћим формама:

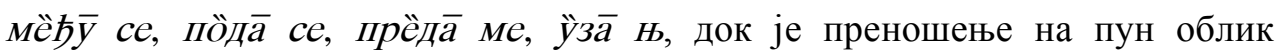
повратне замјенице метатонијско: преко̀ себе (Петровић 1973: 106).

\subsection{2. Новоштокавско преношење акцента са замјеница}

Ново преношење акцента на предлог најчешће је са облика генитива, акузатива и локатива једнине и множине личних замјеница:

ко̀д мене, коेд ње, ко̀(д) тебе, кра̀j тебе, о̀д мене, оे(д) тебе, у̀ мене, у̀

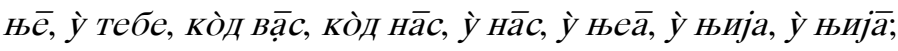

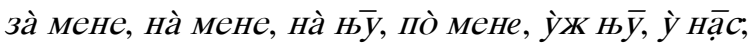
на̀ њему, на̀ њ $\bar{j}$, по̀ мени, по̀ нама. 
Међу наведеним примјерима примјећујемо и генитивну конструкцију с предлогом $y$, која се са истим типом акценатске проклизе остварује и у говору Змијања (Петровић 1973: 133). С друге стране, у источнобосанском ерском говору у вези с овом конструкцијом биљеже се и старо и ново преношење акцента (Реметић 2000: 162-163).

Када се проклитика нађе испред локатива повратне замјенице себе, акценат на проклитици је узлазни:

$$
\text { у̀ себ, у̀ себи. }
$$

Ново преношење остварује се и са облика генитива и инструментала упитно-односних замјеница:

ді̀ којё, о̀т које;

за̀ чйм.

Када се показна замјеница у генитиву, акузативу, инструменталу и локативу једнине нађе иза предлога, акценат се у већини случајева преноси на предлог:

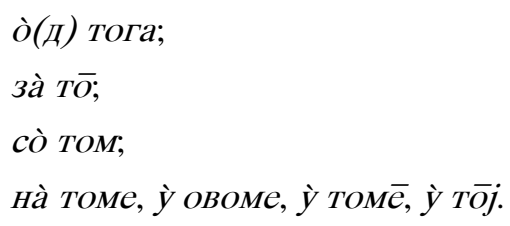

У говору Змијања такође је присутно ново преношење са придјевских

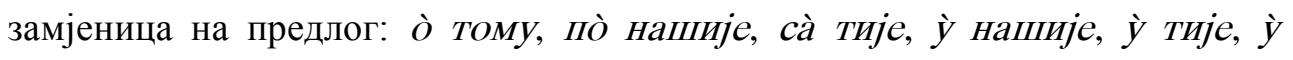
тијем, у̀ ту (Петровић 1973: 19, 107).

На везнике $u$ и ни акценат се најчешће преноси са личних замјеница, и то са облика номинатива једнине и множине готово обавезно:

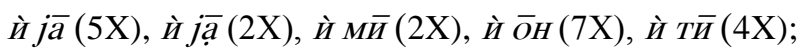

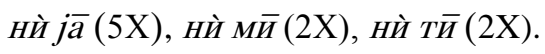

Нови тип преношења акцента на $u$ забиљежен је у неколико примјера и са облика датива и акузатива једнине личних замјеница: 
ѝ мени, й њ $\overline{o j}$;

ѝ $\pitchfork \bar{y}$.

\subsection{3. Конструкције са непренесеним акцентом}

Одступања од проклизе најчешћа су када је проклитика везник $u$. Код појединих информатора налазимо исте примјере, при чему је у једном акценат на везнику, а у другом на замјеници. На примјер, код И1

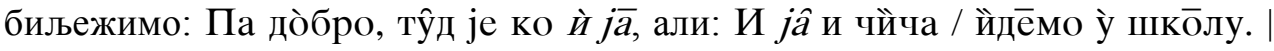
Мо̀ја је ма̂јка у̀мрла, / и ја̂ сам онда по̀шла у̀ шко̄лу. Из ових примјера види се да је разлика у томе што је везник у посљедња два примјера на почетку реченице, односно клаузе. Када је везник у таквом положају, било која ријеч која стоји иза њега задржава свој акценат.

Када се налазе иза саставног везника, са акцентом су редовно биљежени облици номинатива једнине и множине општих замјеница: и свӓко, и свё, и свй, као и показних замјеница: и ӧвй, и ӧво, и ӧно, и тоि. Одрична замјеница ништа у номинативу једнине такође задржава акценат када се нађе иза везника $u$ : и нйшта.

У идиолектима И1 и И3 неодређене замјенице у генитиву, акузативу и локативу иза предлога задржавају акценат:

до нёкобг;

за нёшто, у нёки,

у нёчему.

\subsection{4. Још неке напомене у вези са акцентом замјеница}

Из старије дијалектолошке литературе познато је да облици генитива и акузатива, те датива и локатива једнине личних замјеница 1. и 2. лица и повратне замјенице себе немају исти акценат на цијелом српском језичком простору (Николић 1970: 42). У овој грађи замјенице ван проклизе имају

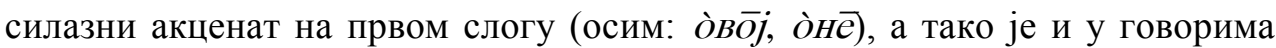
села Буне (Пецо 1957: 11), Змијања (Петровић 1973: 152-153), Баније и Кордуна (Петровић 1978: 31), села Винска (Лукић 2017: 227-228), подручја између Врбаса и Укрине (Козомара 2016: 674), Поткозарја (Далмација 1997: 115-119), Бање Врућице крај Теслића (Драгичевић 2007: 371), Лапачког 
поља (Драгичевић 2009: 331), али и Бачке (Поповић 1968: 113) и југозападне штокавске области (Белић 1999: 221). На облику генитива личних замјеница акценат је силазни и у говорима Пиве и Дробњака (Вуковић 1940: 263-272). Краткосилазни акценат на првом слогу у генитиву-акузативу, дативу-локативу једнине А. Белић (1999: 221) тумачи као утицај инструментала једнине или множинских облика. У говоре који имају узлазне акценте на овим облицима замјеница Б. Николић (1970: 44) сврстао је и Ившићев посавски славонски. У свим наведеним говорима, у којима је на генитивном облику личних замјеница 1. и 2. лица и повратне замјенице силазни акцент, преношење акцента са замјеница у потпуности се слаже са преношењем у говору Баткуше. У говорима у којима је на облицима мене, тебе, себе узлазни акцент преношење је прасловенско. Тако је у тршићком, колубарском, сремском и мачванском: до̆ мене, зӑ тебе, у пљеваљском и поцерском: до̆ себе, кӧд мене, ў тебе (Николић 1970: 43).

У штокавском нарјечју с енклитичких облика замјеница ме, те, се акценат се преноси у виду дугоузлазног (Николић 1970: 47). И у нашој грађи нашли су се примјери на́ се и на́ те. У змијањском говору замјенице често имају краће форме у предлошким конструкцијама: за́ те, на́ ме, на́ те, на́ се, пӧда̄ се, ӱза̄ њга (Петровић 1973: 106).

Као код именица, и код замјеница има примјера дезакцентуације, што изузима могућност проклизе: Доушли су партиза̣́ни и тај Ти́то. | Jâ ѝзишла из оне шу̀пе. | Угледа̄ старјѐшна и дреิкнё на оног мо̀мка. | Је л ѝш̄̄ у оној буิнди сво̀јој? У оваквим спојевима замјеница и именица повезане су истим семантичким обиљежјем, што је довољан услов да чине једну акценатску цјелину. Овакви примјери наведени су и за говор села Винска (Лукић 2018) и за банатске говоре (Ивић et al. 1994: 76).

Када се замјеница шта нађе испред личне замјенице, акцентована је само прва замјеница у синтагми, док је лична замјеница или потпуно ненаглашена: штӓ вас брйга, штӓ ja зна̂м, или чува ненаглашени квантитет: штӓ jāa знамм. Ове двије замјенице једну цјелину чине и са енклитичким обликом глагола хтјети када се нађе између њих: штӓ- $\hbar-j \bar{a}$ ш-њоิм. 


\section{3. Преношење акцента са придјева}

У говору Баткуше забиљежено је само метатонијско преношење акцента са придјева, на једносложне предлоге и везник $u$, мада ни таквих примјера нема много. У грађи за овај рад већина придјева је, по лексичком критеријуму, дио вишечланих назива насељених мјеста и празника, али су у раду наведени и анализирани као придјеви, будући да је грађа класификована по морфолошком критеријуму. Забиљежени су примјери истог придјева који једном предлогу препушта акценат, а пред другим га задржава: ѝз Ба̄ње Лу́ке, али и: у Бӓњ $\overline{o j}$ Лу́ки. Придјев различито задржава акценат и у случају везе са истим предлогом: ѝз Д $\bar{о} \bar{\Gamma}$ Жа̀ба̄ра,

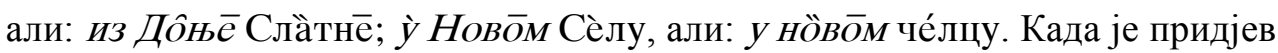
саставни дио назива празника, преношење је досљедно: на̀ Стјепањ да̣̂н, по̀ Ђ̆̄рђеву да́ну. Акценат је пренесен и у примјерима: за̀ сатне оेснове, на̀ исто мјёсто, на̀ истом мјёсту, ѝ Златково̄г, ѝ млӓђйје, ѝ прошле.

Само метатонијско преношење са придјева биљежено је и у централном

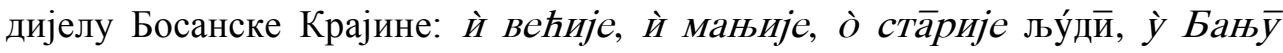

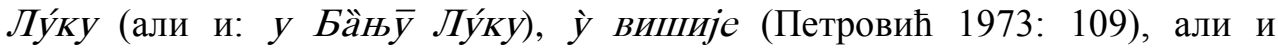

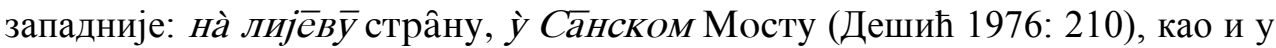
говору села Горње Цапарде код Зворника: на̀ Велкй пе́так, о̀д мла̄де, са̀

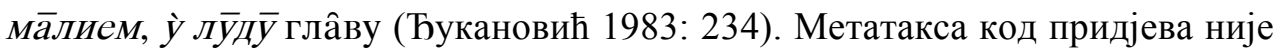
забиљежена ни у Лапачком пољу (Драгичевић 2009: 291-296), ни у говорима између Врбаса и Укрине (Козомара 2016: 667).

\subsection{2. Конструкције са непренесеним акцентом}

С обзиром на то да придјеви нису високофреквентне ријечи и да је њихова употреба условљена темама разговора, губи се свијест о потреби преношења акцента на проклитику (уп. Николић 1970: 36): и ӧчномм, и

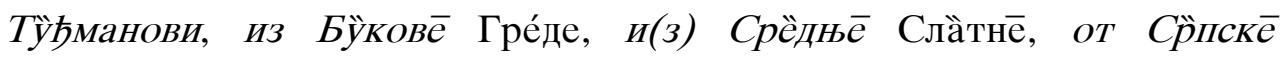

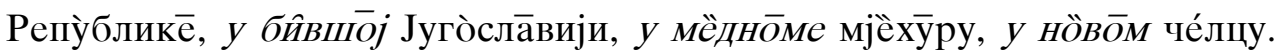
Због ријетког коришћења одређеног облика, понекад долази и до колебања у акценту, па тако ИЗ придјев робна некада изговори са узлазним, некад са

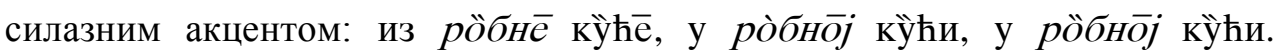


Придјеви, као и друге ријечи, задржавају акценат кад су посебно наглашени и спорије изговорени: $y$ йста̄ до́ба, у йсте мину́те.

\section{4. Преношење акцента са бројева}

У говору Баткуше остварују се и старо и ново преношење акцента са броја, на једносложне предлоге, везнике $u$ и ни, али и на друге бројеве или опште замјенице. Бројеви су једина морфолошка категорија код које су бројнији примјери за метатаксу.

\subsection{1. Прасловенско преношење акцента са бројева}

По старом типу преношења акценат се на проклитику помјера са основних бројева, с тим што је и у конструкцијама типа број један + предлог + падежни облик редног броја „други” на предлогу силазни акценат: од јѐдне дӧ друг $\overline{\mathrm{e}}$ (уп. Петровић 1973: 19, 109; Петровић Савић 2012: 230). Оваква ситуација је и у говорима Поткозарја (Далмација 1997 : 58), околине Теслића (Драгичевић 2007: 354-355), сусједног посавског подручја (Козомара 2016: 668), села Винска (Лукић 2017: 228), Лапачког поља (Драгичевић 2009: 293, 295), долине ријеке Фојнице (Brozović 2012: 346), као и србијанског Полимља (Николић 1991: 52), Колубаре (Радовановић 2007: 154), Рађевине (Петровић Савић 2012: 230). Слични примјери забиљежени су у Бронзаном Мајдану и код Дрвара (Дешић 1976: $210,256)$. За говор околине Шипова констатовано је само да је уобичајено преношење акцента са основног броја, док за редне бројеве нема примјера проклизе: дӧ дв $\bar{a}$, й осмеро, пӧ петеро, пӧ трй (Цукут 2017: 681).

Силазни акценат на предлогу испред основног броја забиљежен је у примјерима:

до̆ двије, зӓ два̣, у̀ два̄.

Прасловенско преношење са бројева у нашој грађи чешће се остварује на везницима $u$ и ни:

й двије, й перт, й трй,

нй пёт, нй шёст. 


\subsection{2. Новоштокавско преношење акцента са бројева}

Малобројни примјери за ново преношење акцента са бројева показују да се оно врши са редних бројева на предлог:

на̀ друге̄, на̀ друго̄.

Преношење акцента са редних бројева новог је типа и у говорима поменутим у тачки 3.4.1. Међутим, у појединим говорима биљежено је старо преношење са редних бројева на предлог. „У говору Баније

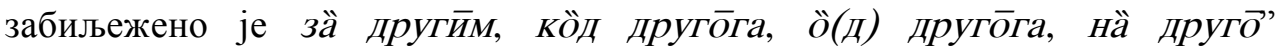
(Далмација 1997: 58). И у хрватском дијелу Посавине преношење са редних бројева је прасловенско (Брозовић 2012: 346).

У примјеру свѐ три акценат је понијела општа замјеница, која није права проклитика. Ново преношење на општу замјеницу може се чути и у Лапачком пољу (Драгичевић 2009: 295) и у околини Шипова (Цукут 2017: 683). У Рађевини је у оваквим конструкцијама силазни акценат на замјеници: свӓ трй, свё трй (Петровић Савић 2007: 229).

\subsection{3. Конструкције са непренесеним акцентом}

Са непренесеним акцентом забиљежено је:

Ша̀тори би́ли вёлки за йљаду и двјёста ду́ша̣.. | Йма оेна моัма̄ка̄ по двӓјес й двије го̆дне.

У другом наведеном примјеру види се да је већи број задржао акценат, а мањи га је препустио проклитици. Поред тога, ово је једини примјер у ком је број двадесет изговорен са силазним акцентом. У свим другим случајевима овај број има краткоузлазни акценат: два̀јез го̀дйна̄, два̀јез да́на, два̀jec й пе̄т краิва, два̀jеc се̂дмо̄ (годиште). За говор Лапачког поља констатовано је да се помјерање на проклитику врши са основних бројева од један до десет (Драгичевић 2009: 293). У нашој грађи нашао се примјер ѝ двјеста, мада исти овај облик иста информаторка други пут изговара са непренесеним акцентом.

У конструкцији $u$ са бројем ортотонична ријеч задржава акценат: 
Сӑд и трй и чѐтир и петт гоัдйн йдӯ за̀једно. | Нйшт нѐ зна̄чи ако је ста̀риј па и ше̂ст-сёдам го̆дйна.

\subsection{4. Још неке напомене у вези са акцентом бројева}

Када се апроксимативност изражава двама бројевима који имају акценте различите интонације, иако се испред силазно наглашеног броја налази проклитика, преношење изостаје: Сваัкй че́лац изнѐсе ѝс кошнице по трй-чѐтри кйле мёда. Разлог овоме је то што је срж семантичке везе између два броја, а не између броја и предлога. Међутим, када два броја исте интонације изражавају приближну вриједност, или долази до прасловенског преношења са првог броја на предлог, док други број

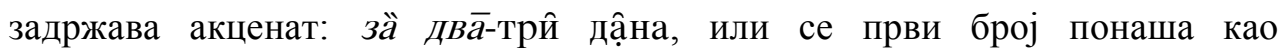
проклитика и са другим бројем чини једну акценатску цјелину, односно фонолошку ријеч, у којој је акценат на првом броју, и то дугоузлазни: пе́-шест. Слично стање забиљежено је у околини Зворника (уп. Ђукановић 1983: 237). Ово је млађа дијалекатска појава (Николић 1970: 51).

\section{5. Преношење акцента са глагола}

У говору Баткуше остварују се и прасловенско и новоштокавско преношење акцента са глагола, на партикулу не и на везнике $u$ и ни.

Преношење на негацију не, прије свега у презенту, досљедно је у свим штокавским говорима са четвороакценатским системом (Николић 1970: 52; Бошњаковић 2009: 79), као и у стандардном језику (Суботић 2005: 143). Овакво стање Б. Николић (1970: 52) објашњава досљедношћу преношења акцента са простог глагола на префикс сложеног глагола, односно чињеницом да предлози који се нађу пред простим глаголом редовно постају префикси сложених глагола. Ситуација код сложених глагола свакако је могла утицати на то да рјечца не и глагол чине једну фонолошку ријеч. Због изразите блискости семантичке везе негације са глаголом, негација не понаша се као префикс.

\subsection{1. Прасловенско преношење акцента са глагола}

Прасловенско преношење најчешће се остварује са облика презента

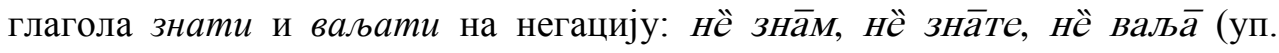


Радовановић 2007: 165; Петровић Савић 2012: 231; Лукић 2017: 230). Старо преношење остварено је и у хабитуалним везама са облика радног глаголског придјева на негацију: Наิј би во̀л:а да се не на̀патим па кад би c'ỳтра ме нё бйло, и на везник $u$ : Та̀к би му й бйло, оेдма̄ ра̀скрстймо, те са аориста глагола попити: Па што ти нё попй соิк? (уп. Драгичевић 2009: 293). У акценатској цјелини й не зна̄м, коју чине три формалне јединице, акценат је на првој јединици, односно на везнику $u$. У околини Шипова забиљежено је: й не зна̄ш (Цукут 2017: 682).

Интересантно је да се са презента глагола знати у говору свих информатора остварују и старо и ново преношење акцента на негацију, мада је чешће старо. Облик са силазним акцентом на негацији прагматички је необиљежен, док облик са узлазним акцентом садржи лични став говорника, сумњу, чуђење или невјерицу: Ни мйлйција нё зна̄ ђе̂, у односу на: Нѐ зна̄м ја̂ ко̀лко̄ Пе́ро ѝма̄ та̀м коัлко не́ма̄. (уп. Лукић 2017 : 230). У опису говора између Врбаса и Укрине на негацији испред презента глагола знати биљежен је само силазни акценат (Козомара 2016: 668), а у говорима Бање Врућице (Драгичевић 2007: 355) и Лапачког поља (Драгичевић 2009: 295) увијек узлазни.

\subsection{2. Новоштокавско преношење акцента са глагола}

Нови тип преношења акцента на негацију само у једном примјеру забиљежен је са инфинитивног облика: За̀р Миिрку на̀ку сва̀дбу оेтрачит, а Не́ди нѐ трачит?, иначе се увијек преноси са облика презента и императива (уп. Петровић Савић 2007: 231; Лукић 2017: 229-230):

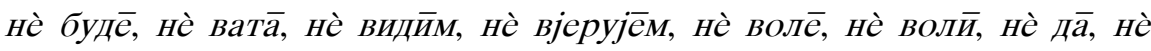

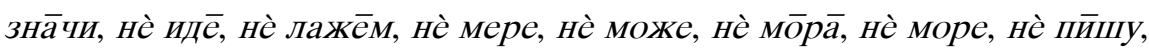

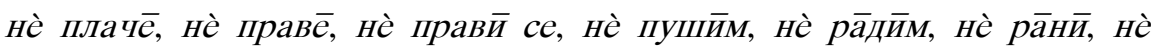
сјећ̄̄м се, нѐ смијём, нѐ треба,;

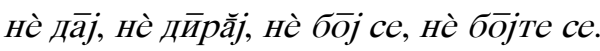

Са ових категорија преношење је метатонијско и у змијањском говору: нѐ ијё, нѐ мере, нѐ меремо, нѐ меш, нѐ ста̄j (Петровић 1973: 113, 114, 118, $124,125)$. Овакав тип преношења забиљежен је и у говорима Бање Врућице 
(Драгичевић 2007: 355) и Лапачког поља (Драгичевић 2009: 295), као и у посавским говорима између Врбаса и Укрине (Козомара 2016: 668).

Примјери нѐ бојйм се и нѐ велй, које изговара И1, аналошки су, јер глаголи са којих је акценат пренесен ван проклизе на првом слогу имају узлазни акценат.

Преношење акцента на негацију са облика аориста глагола бити у склопу потенцијала такође је ново:

нѐ бъ рёко̄, нѐ би пӧније̄ли, нѐ би ра́дла.

У говору Змијања преношење са глагола готово увијек је метатонијско:

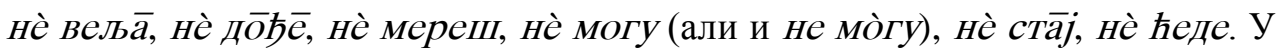
тој студији примијетили смо само један примјер за метатаксу код глагола, и то у аористу: нё осијече (Петровић 1973: 110, 125).

Ново преношење на везник најчешће се врши са одричних облика глагола хтјети и имати:

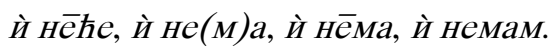

Забиљежено је и неколико примјера новоштокавског преношења акцента на везник са перфекта, тј. радног глаголског придјева: ѝ знала, нй

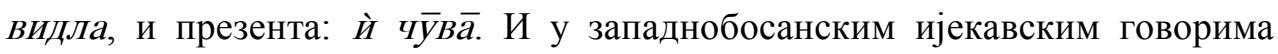

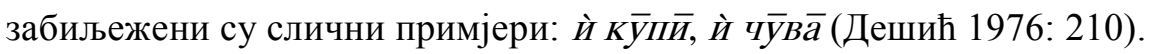

\subsection{3. Конструкције са непренесеним акцентом}

У конструкцијама $\partial a+$ презент нема проклизе:

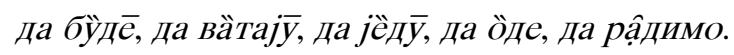

Преношење на везник $u$ са презента изостаје када је глагол у функцији предиката двочлане или вишечлане сложене реченице: Клаัли сёби и јёли, шта̀ ће. | Ја сам ја̀укала и ку̀кала.| Доेбро и жи́вйм йпак и па̀тимм се и раิдйм и свё. | Свё то бу̀де и прођђе, и када се у изговорној цјелини коју 
чине везник и глагол нађе пауза: Ро̀дла муัшко дије́те и / враิтй ма́ло. | Ја праัвйм јёло и тоि је тоि, и / раิдймо зѐмље по̀доста.

\section{6. Преношење акцента са прилога}

У говору Баткуше остварују се и старо и ново преношење акцента са прилога, на једносложне предлоге и везнике $u$ и $н и$.

\subsection{1. Прасловенско преношење акцента са прилога}

Прилози нӓвече, нӓжало̄ст, пӧдалеко, пӧдоста и пӧдуго имају силазни акценат на првом слогу, а стари тип преношења углавном и јесте типичан за овакве прилоге (Николић 1991: 50).

Стари тип преношења уобичајен је са прилога по у конструкцији и по:

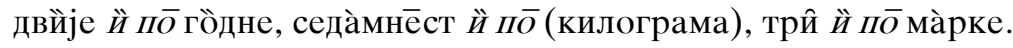

У овој конструкцији на облику по редовно остаје дужина.

Прасловенско преношење акцента забиљежено је и у примјерима:

й даље, йз даље $г, \grave{y ~ б л и ̆ з у . ~}$

\subsection{2. Новоштокавско преношење акцента са прилога}

За ново преношење акцента са прилога на предлог имамо један примјер:

$$
\text { до̀ сада̄. }
$$

По новом типу преношења акценат се са прилога најчешће преноси на везник $u$ :

ѝ ва̣̄мо, ѝ сада̄, ѝ там, й тамо.

У конструкцијама ѝ вако и нй колко̄ преношење је аналошко, јер прилози (о)вако и колко немају силазни акценат на првом слогу: Мён оेво

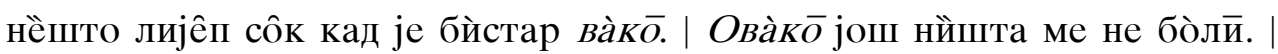
Нѐ зна̄м ја̂ ко̀лко̄ Пе́ро ѝма̄. | Ко̀лко̄ је њйја о́вде раัнйто. 


\subsection{3. Конструкције са непренесеним акцентом}

Прилог задржава акценат када у изговору између прилога и проклитике постоји оклијевање: ии са̀д, пауза: од / поิ, или оба ова фактора: ии / та̀мо. Међу примјерима са непренесеним акцентом истиче се: откаัд, с обзиром на то да се ријетко чује поред устаљеног облика: оेткад.

\section{7. Преношење акцента са рјечце}

Код ове врсте ријечи забиљежена су два примјера новоштокавског преношења, и то на везнике док и $u$ :

Тŷ је бйо до̀(к) год ни́је одвѐжен.

Са̂т заิкључа̄н на банде́ри, тоิ ѝ јест.

\subsection{1. Конструкције са непренесеним акцентом}

Примјер док год забиљежен је и са непренесеним акцентом. Када проклитиком почиње реченица, ријеч иза проклитике задржава акценат:

До(к) гӧд ѝма̄ у̀ себи оно за ле́же̄ње, до̀тле ма̀тица до̀бра.

\section{8. Преношење акцента са предлога}

У грађи се нашао један примјер прасловенског преношења акцента са предлога на везник ни:

\section{Ни́с мйслијо нй на шта.}

Ријеч је о разбијању замјенице ништа предлогом на. Дакле, између негације и замјенице јавила се још једна формална јединица. У оваквом случају, сва три члана чине једну акценатску цјелину, при чему је акценат на негацији (уп. Лукић 2017: 232). 


\section{9. Још неке напомене у вези са преношењем акцента}

У грађи се нашло неколико прилога насталих од прилошких конструкција: нӑвече (предлог + именица), сутра̀да̄н (прилог + именица), са̀свйм (предлог + замјеница), те рјечца нӓжало̄ст (предлог + именица).

Наведени примјери издвојени су јер се данас сматрају правим прилозима, односно рјечцама, иако су некада били спојеви предлога или прилога са одређеним падежним облицима.

Д. Радовановић (2007: 166) сматра да се за ове примјере не може рећи да је ријеч о проклизи, јер су то изведенице настале префиксалном творбом.

Замјеница ишта и прилог откад забиљежени су са непренесеним акцентом: До̀бро је иштӓ ро̀дло. | Откӓд те није́сам вйдјела.

\section{4. Закључак}

Преношење акцента на проклитику у говору Баткуше жива је, али не и апсолутно досљедна појава. Остварују се и стари и нови тип преношења акцента на проклитику у категоријама које могу да учествују у овом процесу, мада не подједнако. Поред правих проклитика - предлога, везника и негације, акценат могу понијети и акцентогене ријечи (пе́-шест, свѐ три). Акценат се преноси чешће на једносложне, а рјеђе на двосложне предлоге, што је и очекивано, јер су двосложни предлози у српском језику знатно малобројнији. На двосложним предлозима пренесени акценат на првом слогу увијек је силазни (йза јутра, мёђу челе, ӧко себе, прёко нӑ̣c), а на

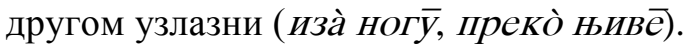

Из старије литературе познато је да што је ријеч дужа, то теже оставља акценат. У складу са тиме, најбројнији су примјери преношења са једносложних и двосложних, а затим и тросложних ријечи. У грађи за овај рад забиљежено је и неколико примјера преношења акцента са четворосложних (йз Дома̄љевца, у̀ кошницама), па и петосложних именица (на̀ Русовићима, у̀ Русовићима).

У говору Баткуше акценат се најактивније преноси са именица, замјеница и глагола.

За преношење акцената са именица можемо рећи да се врши према Даничићевим начелима, мада не толико досљедно. Забиљежено је и 
неколико примјера који одступају од Даничићеве норме (нӑ грббљу, на̀

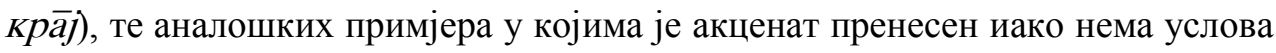
за проклизу (до̀ ће̄рке).

Преношење акцента са замјеница углавном је новоштокавско. Поред

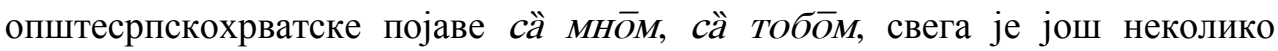
примјера метатаксе код ове врсте ријечи (вёћ онй, й овй, ӧко себе, прёко $\boldsymbol{H a} c)$. Акценатска проклиза у конструкцијама са везницима $u$ и $н и$ и облицима

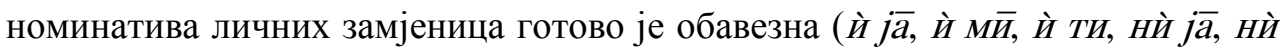
мй, нй $T \bar{и})$.

Преношење акцента са глагола на негацију не, прије свега у презенту, досљедно је у свим штокавским говорима са четвороакценатским системом, као и у стандардном језику. Прасловенско преношење сведено је на глаголе

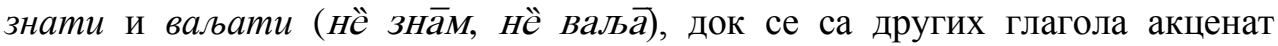
преноси по новом типу, и то најчешће са облика презента и императива (нѐ

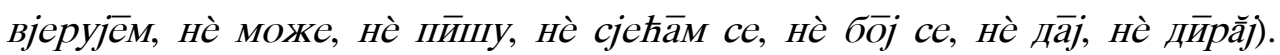
Акценат се на везник $u$ најчешће преноси са презента одричних облика глагола хтјети и имати (ѝ нёће, ѝ нёма). Везници да и па у говору Баткуше никада не носе акценат.

Најмање примјера проклизе забиљежено је код придјева, бројева и прилога. Код придјева је забиљежено само метатонијско преношење, и то углавном са првог дијела вишечланих назива празника и топонима (по̀ Ђӯрђеву да́ну, у̀ Ново̄м Сѐлу).

По правилу, са основних бројева преношење је прасловенско, а са редних метатонијско. Код ове категорије забиљежено је више примјера за старо преношење, јер су основни бројеви у чешћој употреби.

Прасловенско преношење акцента са прилога углавном се види у облицима данашњих изведених прилога (пӧдалеко, пӧдоста, пӧдуго), а по

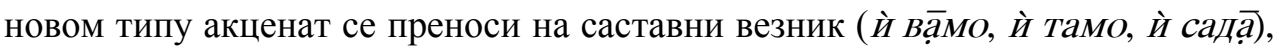
али и на предлоге (доे сада̄, у̀ колко).

Забиљежено је и новоштокавско преношење акцента са рјечце на везник (доे(к) год, ѝ јест). 
Према нашој грађи, (не)преношење акцента на проклитику условљено је факторима као што су: број слогова у акцентогеној ријечи и у предлогу, фреквентност израза, његова семантичка и синтаксичка функција, акценат ортотоничних ријечи и њихова дезакцентуација, говорни темпо, врста конверзације, потреба да се одређене ријечи посебно нагласе.

Већ смо рекли да што је мањи број слогова у акцентогеној ријечи и проклитици, акценат се лакше преноси. Поред тога, ако је ријеч у рјеђој употреби, губи се свијест о потреби преношења акцента на проклитику. У синтагмама које имају адвербијалну функцију акценат је најчешће пренесен. На акценатску проклизу умногоме утиче и врста конверзације. У спонтаним разговорима без задате теме преношење је много чешће него у разговорима са задатом темом. Тако је највише примјера непренесеног акцента са именица забиљежено код информатора који нам говори о пчеларству, вјерујући да о томе ништа не знамо. С друге стране, код истог информатора нема потврде за непреношење акцента са замјеница, јер реченични фокус никада није на њима, него на именицама, односно терминима, због чега се јавља потреба да се оне посебно нагласе. Преношење акцента изостаје и када је ријеч под емфазом (ко(д) цркквё, на ма̣̂jку, у Тйзли!), када се у изговору синтагме јави оклијевање (наа Гарревцу, ии сӓд), пауза (и / дјёд, од / по̂) или самоисправљање (ис по-- ис пӧстељее, до-- до ње̂).

У грађи се нашао и један број дезакцентованих именица и замјеница (баба Са́jа, прија Ạ́нђа, у оној буิнди, из оне шу̀пе̄, и тај Ти́то, на оног мо̀мка), што искључује могућност проклизе. У оваквим спојевима двије именице, или замјеница и именица, повезане су истим семантичким обиљежјем, што је довољан услов да чине једну акценатску цјелину, са акцентом на јединици на којој је тежиште информације. Три формалне јединице чине једну акценатску цјелину и у примјерима: й не зна̄ш, нй на шта, у којима се са акцентогеном ријечју реализују двије проклитике, од којих прва носи акценат.

Поједине ријечи код истог информатора биљежене су једном са пренесеним, други пут са непренесеним акцентом (бёс цйља / са цйљем, прѐт пашу / прет пӓшу), што се може тумачити као посљедица говорног ритма. 
Малобројни радови који се баве екавским говорима урбаних средина показују да у говору млађих генерација екаваца преношење акцената на проклитику готово потпуно изостаје. С друге стране, према досадашњим ријетким истраживањима урбаних говора на ијекавском говорном подручју херцеговачко-крајишког дијалекта може се закључити да је преношење акцената на проклитику сасвим уобичајено, мада се често остварују и непренесени акценти. Према томе, могуће је да се сјевероисточна зона и југозападна и западна зона новоштокавских говора, осим по досљедности преношења акцента на проклитику, разликују и по тенденцији напуштања ове појаве.

По интензитету преношења акцента на проклитику и категоријама у којима се оно врши, стање у говору Баткуше у знатној мјери блиско је приликама које су познате већини говора херцеговачко-крајишког дијалекта.

\section{ЛИТ Е Р А Т У Р А}

Белић, Александар (1999). Историја српског језика: Фонетика. Речи са деклинаиијом. Речи са конјугаиијом. Београд: Завод за уџбенике и наставна средства.

Бошњаковић, Жарко (2007). Преношење акцента у говору неких јавних медија. Зборник Матице српске за филологију и лингвистику. L: 81-93.

Бошњаковић, Жарко (2009). Преношење акцента на проклитику у говору Новог Сада. Лингвистичке свеске. 8. Говор Новог Сада. Свеска 1: Фонетске особине: 79-109.

Вујичић, Д. и др. (1985). Говори сјеверне и сјевероисточне Босне. Босанскохериеговачки дијалектолошки зборник. V: 7-379.

Вуковић, Јован Л. (1940). Акценат говора Пиве и Дробњака. Српски дијалектолошки зборник. Х: 185-417.

Далмација, Стево (1997). Ијекавски говори Поткозарја. Бањалука: Народна и универзитетска библиотека „Петар Кочић”.

Даничић, Ђуро (1925). Српски акиенти. Посебна издања CKA LVIII. Београд: CКА.

Дешић, Милорад (1976). Западнобосански ијекавски говори. Српски дијалектолошки зборник. XXI.

Драгин, Гордана (2000). Две прозодијске појаве говора у сливу Студенице. Зборник Матице српске за филологију и лингвистику. XLIII: 165-171.

Драгин, Гордана (2005). Прозодијске особине говора спикера (новинара) РТВ Нови Сад. Зборник Матице српске за филологију и лингвистику. XLVIII: 277-282.

Драгичевић, Милан (2002). Судбина самогласничких секвенци у данашњем говору требаских Срба. Српски језик. VII/1-2: 205-211. 
Драгичевић, Милан (2003). О говору села Бранешци у околини Челинца. Српски језик. VIII/1-2: 303-314.

Драгичевић, Милан (2004). О неким фонетским особинама данашњег говора требавских Срба. У: Зборник радова са трећег међународног скупа Живот и дело академика Павла Ивића (ур. Ј. Планкош). Суботица - Нови Сад Београд: Градска библиотека - Матица српска - Филозофски факултет Српска академија наука и уметности - Народна библиотека Србије. 451-459. Драгичевић, Милан (2007). О говору Срба Бање Врућице крај Теслића I (фонетске и морфолошке особине). Српски дијалектолошки зборник. LIV: 323-401.

Драгичевић, Милан (2008). Белешке о говору села Кремне у западној Босни. Српски језик. 13/1-2: 103-111.

Драгичевић, Милан (2009). Акценти ријечи у говору Срба Лапачког поља. Српски дијалектолошки зборник. LVI: 277-371.

Драгичевић, Милан (2010). Важније гласовне особине говора Срба из неких насеља у околини Дервенте у северној Босни. Јужнословенски филолог. LXVI: 231253.

Драгичевић, Милан (2011). О морфолошким особинама говора Срба трију насеља из околине Дервенте у северној Босни. Јужнословенски филолог. LXVII: 216239.

Ђукановић, Петар (1983). Говор села Горње Цапарде (код Зворника). Српски дијалектолошки зборник. XXIX: 191-294.

Ивић, Павле (2001). Дијалектологија српскохрватског језика. Увод и штокавско наречје. Сремски Карловци - Нови Сад: Издавачка књижарница Зорана Стојановића.

Ивић, Павле, Жарко Бошњаковић и Гордана Драгин (1994). Банатски говори шумадијско-војвођанског дијалекта. Прва књига: Увод и фонетизам. Српски дијалектолошки зборник. XL.

Козомара, Драгомир (2003). Кратак преглед консонантског система говора села Станари код Добоја. Српски језик. VIII/1-2: 637-643.

Козомара, Драгомир (2005). Говор Чечаве (села у сјевероисточном дијелу општине Теслић). Магистарски рад у рукопису. Бања Лука: Филозофски факултет Универзитета у Бањој Луци.

Козомара, Драгомир (2016). Фонетске и морфолошке особине српских посавских говора између Врбаса и Укрине. Српски дијалектолошки зборник. LXIII: 581-733.

Лукић, Јадранка (2017). Преношење акцента на проклитику у говору села Винска. Прилози проучавању језика. 48: 221-242.

Николић, Берислав (1966). Мачвански говор. Српски дијалектолошки зборник. XVI: $179-314$. 
Николић, Берислав М. (1970). Основи млађе новоштокавске акцентуащије. Београд: Институт за српскохрватски језик.

Николић, Мирослав (1991). Говори србијанског Полимља. Српски дијалектолошки зборник. XXXVII: 1-548.

Павловић, Илија (2013). Родови и крсне славе Баткуше, Брвника и Обудовцุа. Модрича: Српски културни центар.

Петровић, Драгољуб (1973). О говору Змијања. Нови Сад: Матица српска.

Петровић, Драгољуб (1996). Фонетика. У: Српски језик на крају века (ур. М. Радовановић). Београд: Институт за српски језик САНУ. 87-111.

Петровић Савић, Мирјана (2012). Преношење акцента на проклитику у говору Рађевине (на грађи из трију села: Бела Црква, Мојковић и Ставе). Прилози проучавању језика. 43: 215-235.

Пецо, Асим (1957). Говор села Буне. Прилог проучавању говора централне Херцеговине. Зборник за филологију и лингвистику. I: 169-180.

Пецо, Асим (2002). За реформу наше стандардне акцентуације. Научни састанак слависта у Вукове дане. 30/1: 69-72.

Поповић, Иван (1968). Говор Госпођинаца у светлости бачких говора као иелине. Београд: Српска академија наука и уметности.

Радовановић, Драгана (2007). Преношење акцента на проклитику у говору Ваљевске Колубаре. У: Шездесет година Института за српски језик САНУ. Зборник радова (ур. С. Танасић). II. Београд: Институт за српски језик САНУ. $147-$ 168.

Реметић, Слободан (2000). Употреба инструментала у говору источнобосанских Ера. Зборник Матице српске за филологију и лингвистику. XLIII: 505-521.

Симић, Зоран (2004). Преношење акцента на проклитику у говору Гласинца. Probleme de filologie slava. XII: 131-136.

Симић, Милорад (1978). Говор села Обади у босанском Подрињу. Српски дијалектолошки зборник. XXIV: 1-124.

Стевановић, Михаило (1940). Систем акцентуације у пиперском говору. Српски дијалектолошки зборник. Х: 67-184.

Суботић, Љиљана (2005). Ортоепска и ортографска норма стандардног српског језика. Нови Сад: Филозофски факултет. Одсек за медијске студије.

Танасић, Срето (2000). Један тип сложене предлошко-падежне конструкције у говору Вучијака. Зборник Матице српске за филологију и лингвистику. XLIII: 589-593.

Танасић, Срето (2004а). О конструкцији к/ка + датив у говору Срба добојског краја. Српски језик. IX/1-2: 351-357.

Танасић, Срето (2004б). Из синтаксе говора добојског краја: падежи са финалним значењем. У: Зборник радова са трећег међународног скупа Живот и дело академика Павла Ивића (ур. Ј. Планкош). Суботица - Нови Сад - Београд: 
Градска библиотека - Матица српска - Филозофски факултет - Српска академија наука и уметности - Народна библиотека Србије. 479-488.

Танасић, Срето (2006). Један случај модалне употребе футура другог у говору Срба добојског краја. Годишњак за српски језик и књижевност. XX/8: 435-443.

Танасић, Срето (2009). Једна специфична употреба конструкције под + акузатив у српском говору Подновља и околине. Годишњак за српски језик и кьижевност. ХХІІ/9: 493-502.

Трајковић, Татјана (2015). Говор Прешева. Докторска дисертација. Ниш: Филозофски факултет.

Црњак, Дијана (2006). Терминологија куће и покућства у Лијевчу пољу и Жупи. Бања Лука: Филозофски факултет.

Црњак, Дијана (2007). Називи алатки за кошење у Лијевчу пољу и Жупи. Зборник Матице српске за филологију и лингвистику. L: 917-926.

Црњак, Дијана (2009а). Називи ограда и њихових дијелова у Лијевчу пољу и Жупи. Годишњак за српски језик и књижевност. XXII/9: 523-535.

Црњак, Дијана (2009б). Пастирска лексика лакташког краја. Бања Лука: Филолошки факултет.

Цукут, Слађана (2013). Говор младих Дервенте. Магистарски рад у рукопису. Бања Лука: Филозофски факултет.

Цукут, Слађана (2017). Преношење акцента на проклитику у говорима Срба околине Шипова. Српски језик. XXII: 679-686.

Baotić, Josip (1979). Akcenatski sistem sela Kostrča u Bosanskoj Posavini. Bosanskohercegovački dijalektološki zbornik. II: 161-269.

Baotić, Josip (1983). Ikavskošćakavski govor u okolini Dervente. Bosanskohercegovački dijalektološki zbornik. IV: 7-209.

Brozović, Dalibor (2012). Govor u dolini rijeke Fojnice. Bosanskohercegovački dijalektološki zbornik. X: 243-425.

Ivšić, Stjepan (1913). Današnji posavski govor. I. Rad JAZU. 196: 124-254; II. Rad JAZU. 197: 9-138.

Peco, Asim (1971). Osnovi akcentologije srpskohrvatskog jezika. Beograd: Naučna knjiga.

Subotić, Ljiljana, Dejan Sredojević, Isidora Bjelaković (2012). Fonetika i fonologija: Ortoepska i ortografska norma standardnog srpskog jezika. Novi Sad: Filozofski fakultet.

Valjevac, Naila (1983). Govor visočkih muslimana (akcenat i fonetika). Bosanskohercegovački dijalektološki zbornik. IV: 283-354.

Zec, Draga (2000). Prenošenje akcenta na proklitiku pod uticajem rečeničnog fokusa. Зборник Матице српске за филологију и лингвистику. XLIII: 231-242. 


\section{Renata Vidačić}

THE ACCENT SHIFT TO PROCLITICS IN THE SPEECH OF THE VILLAGE OF BATKUŠA NEAR ŠAMAC

\section{SUMMARY}

In this paper we observe the accent shift to proclitic in the village of Batkuša, whose speech belongs to the northeastern region of the Herzegovina-Krajina dialect. This research included accent shift to proclitic of all types of words which participate in this process, and it has been observed by the types of words and the types of shift. The aim of this paper is to show how much the accent shift to proclitic in speech of the village of Batkuša is living phenomenon, in which categories it appears and to what extent, whether there is a tendency to abandon this occurrence, which linguistic and extra-linguistic factors affects its consistency, and how does it relate to situations in neighboring speeches and distant Serbian speeches. The analysis shows that the situation in Batkuša's speech, when it comes to the intensity of the accent shift to proclitic and the categories in which it occurs, is very close to the condition familiar to most of the speeches of the Herzegovina-Krajina dialect.

KEYWORDS: dialectology, the accent shift to proclitic, Herzegovina-Krajina dialect, Posavina speech type.

Мср Рената Видачић

Академија наука и умјетности Републике Српске

Република Српска

rvidacic3@gmail.com 